HARUTYUNYAN AGHAVNI

\title{
CHINA'S “ONE BELT, ONE ROAD” INITIATIVE AND ITS IMPACT IN CENTRAL ASIA
}

Keywords: China, Beijing, Tibet, Central Asia, USSR, "One Belt, One Road", "Western Europe - Western China", Partnership, Economic.

\section{China's relations with the Central Asian states following the USSR collapse}

Following the collapse of the Soviet Union, China has endeavored to build and strengthen its relations with the five Central Asian (CA) states of Kazakhstan, Kyrgyzstan, Tajikistan, Turkmenistan and Uzbekistan.

In January 1992, only one month after founding of the new CA countries, China signed a series of agreements to establish diplomatic relations with all of them. ${ }^{1}$ Since then China and its CA neighbors have developed a close relationship, initially economic but increasingly also political, security ${ }^{2}$ and cultural ties with China. All five countries in the region have

\footnotetext{
${ }^{1}$ Pan Guang, China and Central Asia: Charting a New Course for Regional Cooperation, China Brief, Vol. 7, Issue: 3, The Jamestown Foundation, 09.05.2007.

http://www.jamestown.org/programs/chinabrief/single/?tx_ttnews\%5Btt_news\% 5D=4028\&tx_ttnews\%5BbackPid\%5D=197\&no_cache=1

2 Peyrouse S., Central Asia's Growing Partnership with China, Working Paper, No. 4, 2009, Eu-Central Asia Monitoring, October, 4-13. railwaytechnology.com.http://www.railway-technology.com/features/featurecan-thetrans-caspian-route-deliver-the-next-freight-revolution-4684339/ [08.09.2017]. 
signed strategic agreements with China. High-level visits by Chinese officials have intensified. ${ }^{3}$

In the first half of the 1990s, the main concern of China and CA countries was to demilitarize the borders, sign demarcation treaties and prevent the strengthening of Uighur separatism. In the second half of the 1990s and early 2000s, China aimed at creating a platform for discussion and mutual discovery, and at elaborating a collective security framework. ${ }^{4}$ The primary factor driving Beijing's engagement in CA is the need to stabilize the situation in Xinjiang, decrease the economic marginalization of the latter's ethnic Turkic Uighur population and secure China's western borders against external support for the putative Islamic fundamentalist and separatist movements in the province. Beijing has made CA an integral part of its "develop the west" strategy, in which major economic redistributions from urban eastern China to the Chinese west, primarily Tibet and Xinjiang, have aimed to consolidate national unity and decrease incentives for separatism. ${ }^{5}$ In this regard the Shanghai Five-SCO (Shanghai Cooperation Organization)* process has provided solid structure for China and CA to cooperate closely in combating terrorism, extremism, and separa-

${ }^{3}$ Mariani B., China's Role and Interests in Central Asia, Preventing Violent Conflict. Building Safer Lives. Saferworld, The Grayston Centre, London, October 2013, p. 1. https://www.files.ethz.ch/isn/172938/chinas-role-andinterests-in-central-asia.pdf

${ }^{4}$ Peyrouse S., op. cit.

${ }^{5}$ Swanström N., China's Role in Central Asia: Soft and Hard Power, Global Dialogue, Vol. 9, No. 1-2, Winter/Spring 2007. http://www.worlddialogue.org/content.php?id=402

* The Shanghai Five grouping was created 26 April 1996 with the signing of the Treaty on Deepening Military Trust in Border Regions in Shanghai by the heads of states of Kazakhstan, the People's Republic of China, Kyrgyzstan, Russia and Tajikistan. 
tism as well as various other cross-border criminal activities and military confidence-building measures. ${ }^{6}$

Due to Russia's steep economic decline in the 1990s, the CA states were obliged to secure trade and investments as well as economic and financial aid from outside of Russia. This created the opportunity for the expansion of Chinese trade and investments in the region. ${ }^{7}$ China makes no secret of its attempts to win trade advantages in CA, advantages that can only be won at the expense of Russia, primarily, but also Europe and the USA. ${ }^{8}$ In the first half of the 2000s, China moved to establish itself vigorously on the CA market. ${ }^{9}$ After financial crisis China surpassed Russia as the region's leading trading partner and became de facto the region's largest lender and source of development finance. The Chinese-CA trade reached nearly US $\$ 50$ billion in $2014 .{ }^{10}$

Economic co-operation, integration, and infrastructure projects have also been priority concerns of Beijing. Over the past decade China has strengthened its foothold in CA that has translated into a growing network of infrastructural links (pipelines, railroads, and roads) which ties the rest of the region to western China. ${ }^{11}$ China has made investments in the develop-

\footnotetext{
${ }^{6}$ Pan Guang, op. cit., p. 1.

${ }^{7}$ Berkofsky A., China's Strategic Involvement in Central Asia-Strategies, Results and Obstacles, ISPI - Analysis, No.128, July 2012, p. 1.
}

https://www.ispionline.it/it/documents/Analysis_128_2012.pdf

${ }^{8}$ Swanström N., op. cit., p. 1.

${ }^{9}$ Peyrouse S., op. cit., p. 4.

10 The Silk Road Economic Belt's Impacts on Central Asia, Business News, 19.06.2015. http://businessnews.kg/the-silk-road-economic-belt-s-impacts-oncentral-asia/

${ }^{11}$ Starr F., Svante E. Cornell, Norling N., The EU, Central Asia, and the Development of Continental Transport and Trade, Silk Road Paper, Central Asia-Caucasus Institute \& Silk Road Studies Program - A Joint Transatlantic 286 
ment of trade and in a number of major energy, transport, and mining projects, in CA. ${ }^{12}$ Beijing looks to $\mathrm{CA}$ to reduce its energy deficit, diversify its energy imports and transit routes, and increase its energy security. ${ }^{13}$

Since 2005 Beijing has been hoping to establish ways of promoting the Chinese language and training CA elites according to the Chinese model. ${ }^{14}$ Confucius Institutes, which offer language courses and cultural programs, are present in Kazakhstan, Uzbekistan, Kyrgyzstan, and Tajikistan. The SCO Network University was launched in 2010 as a new platform for cooperation in education and people-to-people exchanges. ${ }^{15}$

Beijing has long been using the Silk Road (SR) discourse in the context of CA. Yet, only recently this discourse emerged as an official Chinese policy.

\section{Chinese One Belt, One Road initiative}

The Silk Road Economic Belt (SREB) and Maritime Silk Road of 21 Century (MSR), also known as the One Belt, One Road initiative (OBOR), is a Chinese-led development framework presented by President of China Xi Jinping during his official visits to Kazakhstan and Indonesia in 2013. ${ }^{16}$

Research and Policy Center, Johns Hopkins University-SAIS, Institute for Security and Development Policy, December 2015, p. 37. http://www.silkroadstudies.org/resources/2015-starr-cornell-norling-eu-centralasia-continental-transport-and-trade.pdf

12 Азизов И., О политике КНР на постсоветском пространстве, Китай на постсоветской пространстве, Российский Институт Стратегических Исследований (РИСИ), Москва, 2012, стр. 8.

${ }^{13}$ Swanström N., op. cit., p. 1.

${ }^{14}$ Peyrouse S., op. cit., p. 4.

${ }^{15}$ Mariani B., op. cit., p. 1.

16 Toktomushev K., Central Asia and the Silk Road Economic Belt, Policy Brief, International Development Research Centre, Centre de Recherches Pour le 
China is mulling six economic corridors with countries along the Belt and Road trade route with funding from the Asian Infrastructure Investment Bank (AIIB) and the Silk Road Fund (SRF). They are as follows:

1. China-Mongolia-Russia Economic Corridor (CMREC);

2. New Eurasian Land Bridge (NELB);

3. China-Central and West Asia Economic Corridor (CCWAEC);

4. China-Pakistan Economic Corridor (CPEC);

5. China-Indo-China Peninsula Economic Corridor (CICPEC); or China-Southeast Asia Corridors;

6. Bangladesh-China-India-Myanmar Economic Corri$\operatorname{dor}(B C I M-E C) .^{17}$

The SREB in geographically economic sense starts from China on the east end of the Eurasia continent, passes through CA, West Asia, South Asia and some other regions by three lines (north line, middle line, and south line), approaches the Caspian, Black Sea, Mediterranean Sea and the Arabian Peninsula, and arrives in Europe and North Africa on the west end of Eurasia. Specifically, the three lines of the SREB are as follows:

1. "North Line": starting from China, via Kazakhstan, through southern Russia, through Ukraine, the Belarus area,

Développement International, Aga Khan Foundation, Graduate School of Development, Institute of Public Policy and Administration, Canada, 2016-1, p. 3.

http://www.ucentralasia.org/Content/Downloads/Central\%20Asia\%20and\%20th e\%20Silk\%20Road\%20Economic\%20Belt.pdf

${ }^{17}$ Vien T., The Grand Design of China's New Trade Routes, Stratfor, 24.06.2015. https://www.stratfor.com/analysis/grand-design-chinas-new-traderoutes 
by Poland and other Eastern European countries, and finally reaches Germany, arriving in Western Europe.

2. "Middle Line": starting from China, via Kyrgyzstan, Tajikistan, Uzbekistan and other Central Asian countries, by Turkmenistan, and continues along the south shore of the Caspian Sea, finally reaching Europe through Turkey.

3. "South Line": starting from China, via Afghanistan, Pakistan, through Iran into the Arabian Peninsula, and then reaches North Africa through Egypt. ${ }^{18}$

In terms of the establishment of the SREB, China needs to properly handle its relations with existing integration organizations and the major powers involved. Within the SREB there is currently a large number of regional cooperation organizations ${ }^{*}$ with varying economic cooperation programs. ${ }^{19}$ China also plans to create a future Free Trade Zone (FTZ) with the $\mathrm{EEU}^{20}$ as the SREB and EEU may focus their attention on the

\footnotetext{
${ }^{18}$ Silk Road Economic Belt: Prospects and Policy Recommendations, Working Papers, Center for China in the World Economy, Tsinghua University China Economic Net, 20.05.2014, p.

34.http://intl.ce.cn/specials/zxxx/201405/26/P020140526515434111874.pdf

* Eurasian Economic Community (EEC), Russia, Belarus and Kazakhstan Customs Union, Eurasian Economic Union (EAEU or EEU), SCO, South Asian Association for Regional Cooperation, Gulf Cooperation Council (GCC) and the Black Sea Economic Cooperation Organization.

${ }^{19} \mathrm{Li}$ Jianmin, Silk Road Economic Zone, the EEU and China-Russia Cooperation, Asia's New Future: Towards a Community of Common Destiny, Boao Forum for Asia, Hainan Province, PRC, March 26-29, p. 12.

HTTP://english.boaoforum.org/u/cms/www2/201503/25112018qw3q.pdf

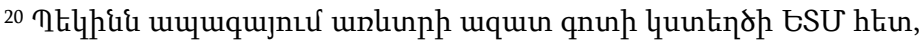
PanARMENIAN.Net, 09.02.2015. http://panarmenian.net/m/arm/news/188060; Посол РФ в КНР: Китай предложил создать зону свободной торговли с ЕАЭС, РИА Новости, 09.02.2015.

http://ria.ru/east_economy/20150209/1046710744.html
} 
following areas as the main directions and prioritize relevant projects. ${ }^{21}$

\section{Chinese One Belt initiative and Central Asian countries}

Chinese concept of SREB first used during the tour committed by President Xi Jinping in the four countries of CA (Turkmenistan, Kazakhstan, Uzbekistan, Kyrgyzstan) which began on 3 September 2013 in Ashgabat and culminated in September 13 at the SCO summit in Bishkek. ${ }^{22}$ Speaking at the Nazarbayev University in Astana, President Xi Jinping expressed the idea of creating a New Silk Road Economic Belt (NSREB) as a new form of deepening cooperation between China, CA and Russia. ${ }^{23} \mathrm{Xi}$ urged countries along the SR to work together for regional development and for this goal made a five-point proposal:

1. to coordinate policy planning and implementation;

2. to improve traffic connectivity to link Eastern, Western and Southern Asia;

3. to facilitate trade and investment for this "unprecedented market" of 3 billion people;

4. to promote local-currency settlement to improve their immunity to financial risks;

\footnotetext{
${ }^{21}$ Li Jianmin, op. cit., p. 13.

${ }^{22}$ Deng Zhimei, The 3rd Central Asia Forum Held in Beijing. The "New Silk Road": An Original Idea for Cooperation between China and Central Asia, Chinese Social Sciences Today, CASS, Beijing, 30.10.2013.

http://casseng.cssn.cn/news_events/news_events_special_report/201402/t201402 28_1006787.html; Центральная Азия: Китайские деньги могут сплотить регион? EurasiaNet, 11.10.2013. http://russian.eurasianet.org/node/60335

${ }_{23}^{3}$ Выступление Председателя КНР Си Цзиньпина в Назарбаев университете (полный текст). Посольство Китайской Народной Республики в Республике Казахстан. 16.09.2013. http://kz.china-embassy.org/rus/zhgx/t1077192.htm
} 
5. to strengthen people-to-people exchanges. ${ }^{24}$

During his trip to $\mathrm{CA}, \mathrm{Xi}$ Jinping signed agreements with four CA states worth more than US\$ 60 billion, ${ }^{25}$ and expressed Beijing's readiness to invest in the region infrastructure more than US $\$ 100$ billion. ${ }^{26} \mathrm{CA}$ is critical in China's OBOR initiative, because it holds the immediate entrance of China's SREB, and is itself a significant destination of Chinese investment. ${ }^{27}$ The westward strategy articulated by Chinese President $X i$ Jinping in his NSREB highlights CA's importance for Chinese economy and development. CA is resource rich, and, because of its proximity to China offers a great opportunity for cheap, reliable energy imports. ${ }^{28}$

SREB was widely supported by CA countries. ${ }^{29}$ Kazakhstan, Uzbekistan, Kyrgyzstan and Tajikistan are among the

\footnotetext{
${ }^{24} \mathrm{Yu}$ Bin, China-Russia Relations, China-Russia Relations: Putin's Glory and Xi's Dream, Comparative Connections, A Triannual E-Journal on East Asian Bilateral Relations, January 2014, p. 4.

http://csis.org/files/publication/1303qchina_russia.pdf

25 Терентьев С. Куда ведёт «Великий шёлковый путь»? Парламентская газета. 07.11.2013. http://www.pnp.ru/column/detail/41015

${ }^{26}$ Дёгтев А. Как Центральной Азии совместить Шелковый путь и ЕАЭС?

Евразийское развитие, 25.11.2014. http://eurazvitiye.org/publication/20141118

${ }^{27}$ Tao Wang, Rachel Yampolsky, Will China and Russia's Partnership in Central Asia Last? The Diplomat, 21.09.2015. http://thediplomat.com/2015/09/willchina-and-russias-partnership-in-central-asia-last/

${ }^{28}$ Marantidou V., Ralph A. C., China and Russia's Great Game in Central Asia, The National Interest, 01.10.2014, p. 1. http://nationalinterest.org/blog/thebuzz/china-russias-great-game-central-asia-11385

${ }^{29}$ Ruan Zongze, What Kind of Neighborhood Will China Build? China Institute of International Studies (CIIS), Beijing, 28.05.2014.

http://www.ciis.org.cn/english/2014-05/28/content_6942279.htm
} 
founding states of AllB founders. ${ }^{30}$ At the third China-Central Asia Co-operation Forum, held in Shandong in June 2015, a commitment to "jointly building the Silk Road Economic Belt" was incorporated into a joint declaration signed by China and the five CA countries. Prior to that, China had signed bilateral agreements on the building of the SREB with Tajikistan, Kazakhstan and Kyrgyzstan, Uzbekistan. This was aimed at further deepening and expanding mutually beneficial co-operation in such areas as trade, investment, finance, transport and communication. The national development strategies of the five CA countries - including Kazakhstan's "Road to Brightness," Tajikistan's "Energy, Transport and Food" (a three-pronged strategy aimed at revitalizing the country), and Turkmenistan's "Strong and Happy Era" - all share common ground with the establishment of the SREB. ${ }^{31}$

\section{NELB or the Second Eurasia Land Bridge and Central Asia}

NELB, also known as the Second Eurasia Land Bridge, is an international railway line running from Lianyungang in China's Jiangsu province through Alashankou in Xinjiang to Rotterdam in Holland. The China section of the line comprises the Lanzhou-Lianyungang Railway and the Lanzhou-Xinjiang Railway and stretches through eastern, central and western China. After exiting Chinese territory, the new land bridge passes

\footnotetext{
${ }^{30} \mathrm{~B}$ китайском инфраструктурном мегапроекте спешат участвовать и Азия, и Европа, Ведомости, 18.03.15.

http://www.vedomosti.ru/newspaper/articles/2015/03/18/ot-redaktsiishelkovaya-sila

${ }^{31}$ The Belt and Road Initiative, HKTDC Research, Hong Kong Trade

Development Council, 21.01.2016, p. 3. http://china-traderesearch.hktdc.com/business-news/article/One-Belt-One-Road/The-Belt-andRoad-Initiative/obor/en/1/1X000000/1X0A36B7.htm
} 
through Kazakhstan, Russia, Belarus and Poland, reaching a number of coastal ports in Europe. ${ }^{32}$

Kazakhstan attaches great importance to the development of major transcontinental transport corridor connecting China and Europe - "Western Europe - Western China." The project will provide transportation on three main directions: ChinaKazakhstan, China - CA, China - Kazakhstan - Russia - Western Europe ("The Road Western Europe-Western Chin").

Kazakhstan aims to increase transport efficiency along the section of the Western Europe-Western China road corridor within Almaty Oblast and to modernize highway management on sections of the Western Europe - Western China road corridor. ${ }^{33}$ The main positive indicators of the project in comparison with existing alternative corridors (Trans-Siberian railway road, sea through the Suez Canal) are its length and hours underway. If it takes up to 45 days travelling along a marine corridor, and 14 days along "Trans-Siberian" railway road, then along the corridor "Western Europe - Western China" from the port Lianyungang to the borders of the European states the travel time will take up only about 10 days. ${ }^{34}$

\footnotetext{
32 Ibid., p. 2; Ким Е. «Таджикистан - Китай - одна семья»: Китай и Средняя Азия, ИА REGNUM, 09.03.2016. http://regnum.ru/news/polit/2093624.html ${ }^{33}$ East-West Roads Project (Almaty-Korgos Section): Western Europe - Western China International Transit Corridor (CAREC - 1b), The World Bank Group, 15.06.2016. http://www.projects.worldbank.org/P128050/east-west-roadswestern-europe-western-china-international-transit-corridor-carec$1 \mathrm{~b}$ ?lang=en\&tab=overview 34 The Road Western Europe - Western China, KAZLOGISTICS, http://www.kazlogistics.kz/en/chain_cluster/road_west/
} 
The completion of the Kazakhstan's section of the international motor road corridor "Western Europe - Western China" was scheduled for 2016. ${ }^{35}$

Now open a second railway line from China through Kazakhstan, Kyrgyzstan and Uzbekistan to Russia and Europe. ${ }^{36}$ However, plans exist to open two more railway routes that may involve Russia, as well: from Xi'an to Rotterdam and from Xi'an to Moscow. ${ }^{37}$

\section{The CCWAEC and CA}

The CCWAEC runs from Xinjiang in China and exits the country via Alashankou* to join the railway networks of CA and West Asia before reaching the Mediterranean coast and the Arabian Peninsula. The corridor mainly covers five countries of

The total length of the corridor along the route St. Petersburg - Moscow Nizhny Novgorod - Kazan - Orenburg - Aktobe - Kyzylorda - Shymkent Taraz - Korday - Almaty - Khorgos - Urumqi - Lanzhou - Zhengzhou Lianyungang is $8445 \mathrm{~km}$. $2233 \mathrm{~km}$ are on the territory of the Russia, $2787 \mathrm{~km}$ belong to the Kazakhstan, $3425 \mathrm{~km}$ belong to the China. $2452 \mathrm{~km}$ of road in Kazakhstan are to be reconstructed.

${ }^{35}$ Kazakhstan to Complete Construction of 'Western Europe - Western China' in 2016, Weekly Ak Zhaik Newspaper, 21.03.2015.

http://azh.kz/en/news/view/6417

36 Что принесет с собой «экономический коридор Шелкового пути»? russian.china.org.cn, 14.10.2013. http://russian.china.org.cn/exclusive/txt/201310/14/content_30289396.htm

${ }^{37}$ Kim A., China and the Silk Road: Marching Westward, Eurasia Daily Monitor, Vol. 11, Issue: 40, The Jamestown Foundation, 03.03.2015.

http://www.jamestown.org/regions/centralasia/single/?tx_ttnews\%5Btt_news\%5 $\mathrm{D}=42035 \&$ tx_ttnews\%5BbackPid\%5D=53\&cHash=d5c439c65fb4c89e9cf645ec5cf 75dd2\#.Vq5GCPnhDIU

* Alashankou is a border city in Bortal Mongol Autonomous Prefecture, Xinjiang Uyghur Autonomous Region, China. It is a port of entry by both railroad and highway from Kazakhstan as part of the Eurasian Land Bridge. 
CA as well as Iran and Turkey in West Asia. ${ }^{38}$ "Chang'an" train, traveling along the 3,860 km Xi'an-Baoji-Urumqi-AlashankouAlmaty route, had departed in November 2013, and arrived in the Kazakhstani city of Almaty within six days. These east-west rail corridors, which bypass Russia, connect China with major destinations within CA, Western Asia and Europe. ${ }^{39}$

More than $5,000 \mathrm{~km}$-long train route proceeding from Xi'an (Chinese Shaanxi) to the Kazakhstani city of Jem (in Aktobe region in the country's west), then passes along the route of Kazakhstan-Uzbekistan-Kyrgyzstan-Turkmenistan. . Since November 2013 it became one of the most convenient ways for freight to move between China and all the countries of CA. The journey time of $6-10$ days along this new east-west corridor is 20 days fewer compared with road travel, reducing transportation costs by $30 \%{ }^{40}$

Automobile highways between China and Kyrgyzstan, Kazakhstan and Tajikistan had opened long ago, and road conditions are gradually improving. They are connected through the road network from the CA to Western Asia and Europe. ${ }^{41}$

\section{Kazakhstan - Turkmenistan - Iran railway line}

CA countries plan to use Iran's railroad network as a transit route from the Inchehboroun border crossing in Iran's northern Golestan Province to southern Iranian port city of

\footnotetext{
38 The Belt and Road Initiative, HKTDC Research, ..., p. 3.

${ }^{39} \mathrm{Kim}$ A., op, cit., p. 1.

* International cargo train Chang'an ("Lasting Peace") is making stops at 9 stations in these countries, including such cities as Pavlodar, Meteo, Kostanay, Shymkent, Tashkent, Sergeli, Alamedin, Chukursai and Farap.

${ }^{40}$ Ibid., p. 1.

41 Что принесет с собой «экономический коридор Шелкового пути»? ..., стр. 1.
} 
Bandar Abbas. They are also willing to transit their needed commodities from Bandar Abbas to CA using Iran's railroad network. ${ }^{42}$

An important project is a railway line "Kazakhstan Turkmenistan - Iran," which as a part of "North - South" transport corridor ${ }^{*}$ planned to connect the markets of Russia, China, countries of CA and the Middle East. ${ }^{43}$ In December 2011, the transport corridor "North-South" completed construction of a new railway line Uzen - the boundary of Turkmenistan. ${ }^{44}$ This branch is directly connected Kazakhstan with Iranian trading port of Bandar Abbas. ${ }^{45}$

The railway line "Kazakhstan - Turkmenistan - Iran"

\footnotetext{
42 Central Asian Countries Choose Iran as Transit Route for Bulk Cargoes, PressTV, 13.06.2015. http://www.presstv.ir/Detail/2015/06/13/415655/iranrailroads-Central-Asia-Hossein-Ashouri-
}

As a first step, the CA countries are planning to carry 500,000 tonnes of chemical fertilizer from Kazakhstan and Uzbekistan to Bandar Abbas during the current Iranian calendar year (started on March 21, 2015).

* International North-South Transport Corridor (INSTC) is the ship, rail, and road route for moving freight between India, Russia, Iran, Europe and CA. It is a not a new concept, but the current INSTC project was initiated by Russia, India and Iran in September 2000 in St. Petersburg. The agreement was signed on $16^{\text {th }}$ May 2002.

43 Что ждет Центральную Азию в 2015 году: 10 важнейших событий, Власть, 31.01.2015.

http://m.vlast.kz/article/chto_zhdet_centralnuju_aziju_v_2015_godu_10_vazhne jshih_sobytij-9421.html

44 Лабыкин А., «Новый шелковый путь» для Китая, Expert Online, Москва, 14.11.2014. http://expert.ru/2014/11/14/novyij-shelkovyij-put/

45 Ордабаев А. Геополитика транспортных коридоров в Центральной Азии. Институт мировой экономики и политики при Фонде Первого Президента Республики Казахстан - Лидера Нации, Астана - Алматы. Апрель 2015, стр. 14. http://iwep.kz/files/attachments/article/2015-05-12/geopolitika_tk.pdf 
opened in December 2014. ${ }^{46}$ The sides have already signed an agreement to determine a single tariff rate in line with the three countries' policy to reduce transit tariffs. ${ }^{47}$

First pilot cargo train has passed through Kazakhstan and Turkmenistan to Iran, travelling a distance of 10,399 $\mathrm{km}$. It had left Yiwu city in East China's Zhejiang province on January 28, 2016 and arrived in Tehran on February 15, 2016. ${ }^{48}$ Compared to the sea voyage of the cargo ships from China's Shanghai city to Iran's Bandar Abbas port city, the travel time of the train was 30 days shorter. ${ }^{49}$ An Iranian container ship, the Perarin, arrived in Guangxi in southern China a month earlier, delivering 978 containers from a number of countries along the maritime route. ${ }^{50}$

In May of 2016, freight train from Zhejiang province reached Iran via Kazakhstan and Turkmenistan for 14 days, although Tehran intends to speed up the trip to 12 days. For comparison: the way by sea from China to Iran takes about 45

\footnotetext{
46 Нурмурадов А. Запущен первый тестовый поезд Китай-КазахстанТуркменистан-Иран, zakon.kz, 11.02.2016. http://www.zakon.kz/4774415zapushhen-pervyjj-testovyjj-poezd.html

${ }^{47}$ Central Asian Countries Choose Iran as Transit Route for Bulk Cargoes, ..., p. 1. Iran and Kazakhstan have agreed to enforce a single tariff rate for transit commodities and Turkmenistan is expected to adopt the single tariff.

${ }^{48}$ China's Silk Road Revival Steams ahead as Cargo Train Arrives in Iran, The Guardian, 15.02.2016.

http://www.theguardian.com/business/2016/feb/15/chinas-silk-road-revivalsteams-ahead-as-cargo-train-arrives-in-iran

${ }^{49}$ Нурмурадов А. Запущен первый тестовый поезд Китай-Казахстан-

Туркменистан-Иран, ..., стр. 1;

First Train from China to Iran Stimulates Silk Road Revival, Xinhua, China

Daily, 16.02.2016. http:/www.chinadaily.com.cn/business/2016-

02/16/content_23499170.htm
}

${ }^{50}$ China's Silk Road Revival Steams ahead as Cargo Train Arrives in Iran, ..., p. 1. 
days. After completion of missing links construction in the path on the borders with Afghanistan and Iraq, Iran will turn into the main corridor for the delivery of goods to these countries. ${ }^{51}$

\section{Kazakhstan, Kyrgyzstan, Uzbekistan, Turkmenistan and Iran railway}

China's railway authority has put forward another ambitious plan to build a SR high-speed railway which would connect northwest China to West Asia via CA. The route would lead from China's Urumqi and Yining to Almaty in Kazakhstan, followed by Bishkek in Kyrgyzstan, Tashkent and Samarkand in Uzbekistan and Ashgabat in Turkmenistan before finally joining the train network in West Asia through Tehran, Iran. ${ }^{52}$

\section{Iran, Tajikistan, Kyrgyzstan and China railroad project}

Agreement to conduct feasibility studies on a railroad project that would connect Iran to Afghanistan, Tajikistan, Kyrgyzstan and China was signed by all involved sides in October 2010. The railroad will reduce the distance for commercial transport between the East (from China to Iran) and the West (toward Western Europe) and help connect member countries to the free waters of the Persian Gulf (PG) through the Iranian

\footnotetext{
${ }^{51}$ Цатурян С. Китай подбирается к Евросоюзу через Иран ИА REGNUM, 17.05.2016. https://regnum.ru/news/polit/2132826.html

52 China Proposes High-speed Rail Line Connecting Western China to Iran, Shanghaiist, 21.11.2015.

http://shanghaiist.com/2015/11/21/china_proposes_silk_road_high_speed_rail_li ne.php
}

For years, the 1.52-meter track standard adopted in Central Asia has been a headache for logistics managers because it is not based on the 1.435-meter standard track adopted in China and most other parts of the world. Changing gauges at the border takes days for cargo and significantly cuts railway transport's competitiveness against shipping by sea. 
soil. ${ }^{53}$ Iran, Afghanistan, Tajikistan, and Kyrgyzstan reaffirmed the importance to construct a railway - then called the NorthSouth Corridor - in July 2012. The length of the railway linking China's Kashgar city with Afghanistan's Herat city would be $1,972 \mathrm{~km}$. The length of the Tajik section of this railway, running from the Nizhny Panj to the border with Kyrgyzstan will be $296 \mathrm{~km}$. Iran expressed its readiness to finance the Kyrgyz section of the railway. ${ }^{54}$

Establishment of a land transport corridor and construction of railroad through Afghanistan's soil is much more important for Tajikistan for it connects Tajikistan directly to Afghanistan and indirectly to Iran, as two Persian-speaking countries, and reduces the country's political reliance on Uzbekistan and Russia. It will also further shorten the existing route that connects China to West Asian countries, and the Middle East in order to export and import goods and also to take oil products from the PG region. ${ }^{55}$

\section{China-Kyrgyzstan-Uzbekistan railway line}

Another railway project plans to build the ChinaKyrgyzstan-Uzbekistan railway. It will connect Kashgar (Xinjiang) to Kyrgyzstan and Uzbekistan, with the Kyrgyz link connecting through Tajikistan onward to Iran and the countries of

\footnotetext{
${ }^{53}$ Farzad Ramezani Bonesh, Various Benefits of Rail Route Connecting Iran To Afghanistan, Tajikistan, Kyrgyzstan And China, Eurasia Review, 26.01.2016. http://www.eurasiareview.com/26012016-various-benefits-of-rail-routeconnecting-iran-to-afghanistan-tajikistan-kyrgyzstan-and-china/ ${ }^{54}$ Tajikistan Looking forward to North Corridor Operation, European Dialogue, 19.06.2015.

http://eurodialogue.eu/Tajikistan\%20looking\%20forward\%20to\%20north\%20co rridor\%20operation

${ }^{55}$ Farzad Ramezani Bonesh, op. cit., p. 1.
} 
the PG. ${ }^{56}$ In 2012 Chinese Construction Corporation CRBC* agreed to perform a feasibility study for the project. The railway line would go from Kashgar in Xinjiang, through Torugart and Kara-Suu in Kyrgyzstan, to Andijan in Uzbekistan, then across Afghanistan, Iran and Turkey as far as Europe. The Kyrgyzstan section of the line would cover $268.4 \mathrm{~km}$; China's section would span $165 \mathrm{~km}$. The cargo transit capacity of the line was expected to be approximately 15,000 tons. ${ }^{57}$

In early September 2015, the Uzbekistan Railways Co. announced that it finished the construction of $104 \mathrm{~km}$ of the $129 \mathrm{~km}$-long Angren-Pap railway line, which was expected to be commissioned in the second half of 2016. The Angren-Pap railway will connect Uzbekistan's eastern provinces bordering on Kyrgyzstan to the rest of the domestic rail network. ${ }^{58}$

The railway is expected to help Kyrgyzstan enhance its position as a transit state in the land-locked region, connect to the Pacific Ocean, and link its economy to that of the outside world. For China, it is projected to complement the overloaded Trans-Siberian and Alashankou corridors, to accommodate its expanding trade across Eurasia, stimulate development of Western provinces and pave the way for further economic in-

\footnotetext{
${ }^{56}$ Starr S. F., Cornell Svante E., Norling N., op. cit., p. 37; Ким E., op. cit., p. 1.

* China Road and Bridge Corporation (CRBC) is a subsidiary of China Communications Construction Company (CCCC).

${ }^{57}$ Muzalevsky R., China-Kyrgyzstan-Uzbekistan Railway Scheme: Fears, Hopes and Prospects, Eurasia Daily Monitor, Vol. 9, Issue: 102, The Jamestown Foundation, 30.05.2012. https://jamestown.org/program/china-kyrgyzstanuzbekistan-railway-scheme-fears-hopes-and-prospects/

${ }^{58}$ Fozil Mashrab, Bishkek Puts Brakes on China-Kyrgyzstan-Uzbekistan Railway, Eurasia Daily Monitor, Vol. 12, Issue: 199, The Jamestown Foundation, 03.11.2015. https://jamestown.org/program/bishkek-puts-brakes-on-chinakyrgyzstan-uzbekistan-railway/
} 
roads into the resource-rich CA region. ${ }^{59}$ If realized, the China-Kyrgyzstan-Uzbekistan line is expected to become part of the shortest railway link connecting the China with the oil rich Middle East and the enormous European market via CA. ${ }^{60}$

Some Russian analysts openly argue against the construction of the China-Kyrgyzstan-Uzbekistan railway line by claiming that it runs counter to Russia's own efforts to position itself as the bridge between Asia and Europe. Bilateral disputes between Kyrgyzstan and Uzbekistan related to border demarcation, trans-boundary river usage, gas supply disputes, or growing state-condoned discrimination against the ethnic-Uzbek minority in Kyrgyzstan, can also act as spoilers for this important railway project. ${ }^{61}$

The Kyrgyz Republic's government has repeatedly made clear to China that its own railway preference is for a northsouth line to help unite the country rather than an east-west railway to facilitate the transit of Chinese merchandise. ${ }^{62} \mathrm{Re}-$ cently China and Kyrgyzstan discussed a new project linking Kyrgyzstan with China. ${ }^{63}$

\section{Hairatan-Uzbekistan Rail Project}

A logical extension of the railway China - Kyrgyzstan Uzbekistan has seen the construction of the $75-\mathrm{km}$ rail link

\footnotetext{
${ }^{59}$ Muzalevsky R., op. cit., p. 1.

${ }^{60}$ Fozil Mashrab, op. cit., p. 1.

${ }^{61}$ Ibid., p. 1.

${ }^{62}$ Daly J. C. K., China and Kyrgyzstan Discuss Rail Projects, Eurasia Daily

Monitor, Vol. 11, Issue: 29, The Jamestown Foundation, 13.02.2014.

https://jamestown.org/program/china-and-kyrgyzstan-discuss-rail-projects/

${ }^{63}$ Kyrgyztan Plans on Railway Project with China, English.news.cn,

21.01.2015.http://news.xinhuanet.com/english/china/2015-

01/21/c_133933773.htm
} 
connecting Hairatan on the Uzbekistan-Afghan border to the city of Mazar-i-Sharif in northern Afghanistan. The construction of the project was started in January 2010 and completed in November 2010. The line will run mainly through uninhabited areas, and million tons of goods are expected to be transported benefiting up to five million people. The estimated cost of the project was US $\$ 170 \mathrm{~m}$, of which US $\$ 165 \mathrm{~m}$ was provided by the Asian Development Bank (ADB). The project is being constructed by Uzbekistan's state rail company.$^{64}$ It bypasses both Russia and Iran and have an importance for the withdrawal of international troops from Afghanistan as an element of socalled "Northern Route."65

Meanwhile, the highway from Mazar-i-Sharif to Herat may no longer meet the interests of the Uzbek side, after it became known, that Dushanbe and Bishkek were seeking the railroad from China to be continued through the territory of Tajikistan. ${ }^{66}$

\section{Trans-Caspian International Transport Routes (TITR)}

The Caspian region stands as one of the most important levers of embedding areas of the Eurasian continent in the sphere of influence of the geopolitical centers of power. ${ }^{67}$ In this regard the implementation of an upcoming multimodal

\footnotetext{
64 Kucera J., Uzbekistan Starts Building Railroad to Mazar-e-Sharif, Eurasianet.org, 29.05.2010. http://www.eurasianet.org/node/61183

${ }^{65}$ Ордабаев А., ор.cit., p. 21.

${ }^{66}$ Ibid., p. 21.

${ }^{67}$ Мураталиева Н. Роль Каспийского региона в системе геополитической конкуренции за Евразийский континент. Caspian Bridge - Информационноаналитический центр, 04.05.2014.

http://www.caspiania.org/2014/05/04/rol-kaspijskogo-regiona-v-sistemegeopoliticheskoj-konkurencii-za-evrazijskij-kontinent/ 
transport route has the potential to shift the power dynamics in global freight. Initiated by the governments of China, Kazakhstan and Azerbaijan, the Trans-Caspian International Transport Route (TITR) aims to reinvigorate foreign trade and cargo transportation between China and Europe, via CA and the South Caucasus region. ${ }^{68}$

In 19 November, 2015 China, Kazakhstan, Georgia, Azerbaijan and Turkey agreed to establish a consortium for the transportation of goods from China to Europe via the TITR. TITR runs from China through Kazakhstan, the Caspian Sea, Azerbaijan, Georgia, and Turkey and further via Ukraine to Europe. ${ }^{69}$ Experts forecast that trade turnover along the TITR will increase from US $\$ 646$ to US\$ 922 billion by $2020 .^{70}$

A first pilot container train, the Nomad express, from Shihezi, China, to Georgia via Kazakhstan (Dostyk-Aktau port) and Azerbaijan (Kishly) launched in July 2015 and has arrived at Baku International Sea Trade Port in August 3, 2015. Distance length of $4726 \mathrm{~km}$ the train crossed for 6 days. ${ }^{71}$ The second container train via the TITR arrived in Georgia

${ }^{68}$ Can the Trans-Caspian Route Deliver the Next Freight Revolution?

www.railway-technology.com. http://www.railway-

technology.com/features/featurecan-the-trans-caspian-route-deliver-the-next-

freight-revolution-4684339/

${ }^{69}$ Страны Азии проложат "шелковый путь" через Украину. Корреспон-

дент, 30.11.2015. http://korrespondent.net/business/companies/3596749-stranyazyy-prolozhat-shelkovyi-put-cherez-

ukraynu?utm_source=facebook.com\&utm_medium=social\&utm_campaign=3596 749

70 Trans-Caspian Int'l Transport Route potential presented in Vienna, Казинформ, 23.09.2016. http://www.kazinform.kz/ru/trans-caspian-int-ltransport-route-potential-presented-in-vienna_a2952002

${ }^{71}$ Порты: экспансия Китая в Прибалтику и «шелковый путь» в обход России, NA REGNUM, 01.12.2015. http://regnum.ru/news/economy/2024288.html 
via Azerbaijani in October 2015. Regular container Nomad Express will offer services for China - Kazakhstan - Azerbaijan Georgia -Turkey (Istanbul) route. ${ }^{72}$ The 4,766 km-long multimodal route is eventually expected to have an annual capacity of $27.5 \mathrm{~m}$ tons of containerized cargo and to be able transport up to 300,000 TEU (twenty-foot equivalent unit) per annum by $2020 .^{73}$

In December 2015, in the framework of NSR in order to significantly reduce the cost of transportation of goods from China to Europe, the first transit cargo train arrived from China to Georgia via territory of Kazakhstan and Azerbaijan, bypassing Russia, and aiming to continue the path to Turkey. The loads entered Georgia in an unprecedentedly short period of time - 8-10 days. Later they were sent to different countries of Europe within 3-5 days. Before that, the cargo transportation from China to Europe was carried out by sea and took about 40 days. In the Kazakh city of Aktau the train moved to ferry line and after 12 hours it turned out in Azerbaijani Alat port on the other side of the Caspian Sea. In Georgia, the train reached the port of Poti and after crossing the Black Sea got Istanbul. ${ }^{74}$

\footnotetext{
${ }^{72}$ Ibid., p. 1; Consortium on China-Europe via Turkey Freight Transport to be Established, Think Railways, 01.12.2015. http://www.thinkrailways.com/consortium-on-china-europe-via-turkey-freight-transport-to-beestablished/

${ }^{73}$ Trans-Caspian International Transport Route (TITR) Tariff Protocol Signed, Eurasian Business Briefing, 15.01.2016.

http://www.eurasianbusinessbriefing.com/trans-caspian-international-transportroute-titr-tariffs-agreed/\#more-23658

${ }^{74}$ Фохт Е. Первый поезд по-новому «Шелковому пути» в обход России прибыл в Грузию. РосБизнесКонсалтинг (РБК), 13.12.2015.

http://www.rbc.ru/business/13/12/2015/566d50109a79472274a8feec?from=main 304
} 
The TITR parties also want to launch the transportation of goods to Northern and Eastern Europe via Ukraine ${ }^{75}$ and as well to the Baltic States. ${ }^{76}$ Ukraine - Georgia - Azerbaijan - Kazakhstan - China route, as a new and alternative direction of the SR, will help to redirect traffic flows in an easterly direction bypassing Russian territory and is set to become competitive in comparison to the traditional overland route. It includes ferry crossings of the Black and Caspian seas (Illichivsk - Batumi and Alyat - Aktau port). The railway follows Kiev - Zhmerynka Odessa and Poti - Tbilisi - Baku routes. Ferries on the Black Sea go from Odessa to Poti and on the Caspian Sea from Baku to Aktau. The goods then travel from Aktau all over Kazakhstan. The transit of goods to China will be made via Aktau Astana - Dostyk route, to Kyrgyzstan via the Aktau port - Shu Bishkek route and to Uzbekistan, Tajikistan and Turkmenistan via the Aktau - Beineu - Kungrad - Altynkul port. With the capability, goods from CA and Kazakhstan will be delivered to Ukraine, Azerbaijan, Georgia, Latvia, Lithuania, Estonia, Poland and the countries of the EU by container train named "Friendship." The first trial run of a container train following the

\footnotetext{
75 Порты: экспансия Китая в Прибалтику и «шелковый путь» в обход России, ..., p. 1; Turkey, Kazakhstan, Azerbaijan and Georgia will Create a Transport Consortium, Real Russia Today, 03.12.2015.

http://realrussiatoday.com/2015/12/03/turkey-kazakhstan-azerbaijanand-georgia-will-create-transport-consortium/; Turkish-Kazakh-AzeriGeorgian Consortium to Transport Cargo from China to Europe Via Ukraine, Center for Transport Strategies (CTS), Kiev, 01.12.2015.

http://en.cfts.org.ua/news/turkish_kazakh_azeri_georgian_consortium_to_transp ort_cargo_from_china_to_europe_via_ukraine

${ }^{76}$ Consortium on China-Europe via Turkey Freight Transport to be Established, Think Railways, 01.12.2015. http://www.think-railways.com/consortium-onchina-europe-via-turkey-freight-transport-to-be-established/
} 
Ukraine - Georgia - Azerbaijan - Kazakhstan - China route left the Odessa region in Ukraine in January 15, 2016. ${ }^{77}$

\section{Russian-Chinese geopolitical competition for Central Asia}

No other place will provide more fertile ground for Russian-Chinese geopolitical competition than their shared periphery, the CA - Russia's "near abroad. "Now the local dynamic of Sino-Russian relationship in the region is shifting as China is slowly displacing Russia. This will have consequences for China's responsibilities and on how the region looks to Beijing as it goes from passive trade partner to major security and foreign policy partner.$^{78}$ Russia has survived as the dominant power in CA only because the area was poor and economically backwards enough to escape global attention. ${ }^{79}$ Economically, Russia is still important for CA's countries and remittances from CA's workers in Russia sustain their economies. ${ }^{80}$ However, China is becoming much more attractive market to CA states

\footnotetext{
${ }_{77}$ Dyussembekova Zh., Silk Road Renewed with Launch of New Commercial Transit Route, The Astana Times, 21.01.2016.

HTTP://ASTANATIMES.COM/2016/01/SILK-ROAD-RENEWED-WITHLAUNCH-OF-NEW-COMMERCIAL-TRANSIT-ROUTE/

${ }^{78}$ Pantucci R., Is China Prepared for a New Mantle in Central Asia Amid the Roll-out of its Belt and Road? China in Central Asia, 28.03.2017.

http://chinaincentralasia.com/2017/03/28/is-china-prepared-for-a-new-mantlein-central-asia-amid-the-roll-out-of-its-belt-and-road/

${ }^{79}$ Neil T., China's Growing Presence in Russia's Backyard, The Diplomat, 25.03.2015. http://thediplomat.com/2015/03/chinas-growing-presence-inrussias-

backyard/?utm_content=buffer4d126\&utm_medium=social\&utm_source=facebook.co m\&utm_campaign=buffer

${ }^{80}$ Rising China, Sinking Russia, The Economist, 14.09.2013.

http://www.economist.com/news/asia/21586304-vast-region-chinas-economicclout-more-match-russias-rising-china-sinking
} 
than Russia that is presently reeling under the weight of collapsing energy prices and Western sanctions. China has already had a transformational effect on the economies of CA states, where it sits at the center of a spider's web of production, with parts and materials of goods crossing borders in multiple directions before assemblage. ${ }^{81}$

Beijing has been pushing for further economic integration with the CA countries even through the SCO, but Kremlin resisted the Chinese efforts to evolve the SCO in a more economic and development direction. ${ }^{82}$ The fact is that Russia has resisted any multilateral framework that is not under its leadership. China is also suspicious of organizations that it does not control. It is not clear if SCO can reconcile and contain the pressures created by the two countries' competing visions of regional economic integration..$^{83}$ However, Beijing believes, that Eurasian Economic Community can collaborate within the framework of the SREB; it also assumes SCO member - countries, observers and SCO dialogue partners' association on the basis of SR. ${ }^{84}$

Russia still controls the majority of CA's energy exports and for years has treated the region as its exclusive province,

\footnotetext{
${ }^{81}$ Neil T., op. cit., p. 1.

${ }^{82}$ Kamel T., The Silk Road Economic Belt's Impacts on Central Asia, China and US Focus, China United States Exchange Foundation, 08.05.2015.

http://www.chinausfocus.com/finance-economy/the-silk-road-economic-beltsimpacts-on-central-asia/

${ }^{83}$ Marantidou V., Ralph A. Cossa, op. cit., p. 2.

${ }^{84}$ Арутюнян А. Геополотический выбор Южного Кавказа и Китай, Круглый стол «Геополитический выбор Южного Кавказа», Российский институт стратегических исследований (РИСИ) и Институт востоковедения Национальной академии наук Республики Армения (ИВ НАН РА), 17 января 2014 года. http://www.riss.ru/actions/2601-kruglyj-stol-geopoliticheskij-vyboryuzhnogo-kavkaza\#.UwYm82J_vFA
} 
insisting on buying oil and gas at below-market rates through Soviet-era pipelines, while re-exporting it at a markup. But in effect the practice helped drive Kazakhstan and Turkmenistan, both with huge energy reserves, into China's arms. Turkmenistan already became China's largest foreign supplier of natural gas. Production at the world's second-biggest gas field, Galkynysh, will help triple Chinese imports from the country. In Kazakhstan, US\$ 30 billions of announced deals including a stake in Kashagan, the world's largest oil discovery in recent decades, has been reached with China. In Uzbekistan, China obtained US\$ 15 billion worth of oil, gas and uranium deals. ${ }^{85}$ The China-Central Asia network of pipelines could supply up to 55 billion cubic meters of natural gas to China every year, or more than half of China's total gas imports. ${ }^{86}$

China and Russia are competing as well in CA for influence of international transport corridors. Beijing wants to connect the CA to the international transport corridors through building of the SREB and thereby increase the transit traffic from southern China and the countries of Northeast and Southeast Asia to the countries of CA and Europe by the shortest routes, i.e., by passing most of the TRANSSIB and other Russian transport systems. ${ }^{87}$ Beijing and Moscow are competing in part over the railroad gauge to be used by those states with China's loans likely predicated on using China's standard gauge. $^{88}$

\footnotetext{
${ }^{85}$ Rising China, Sinking Russia, ..., p. 1.

${ }^{86}$ Tao Wang, op cit., p. 1. Since independence, Kyrgyzstan received nearly US\$ 1.8 billion from China in the form of loans and grants, which stands for more than half of Kyrgyzstan's external debt.

${ }^{87}$ Азизов И. О политике КНР на постсоветском пространстве, ..., стр. 8.

${ }^{88}$ Beauchamp-Mustafaga N., Rolling out the New Silk Road: Railroads Undergird Beijing's Strategy, China Brief, The Jamestown Foundation, Vol.: XV, Issue 8, 
It is worth noting that CA elites perceive the Beijing-led regional architecture as a tool of China to assert its regional hegemony and those views prevail in neighboring Russia as well. Beijing's new role as the main economic and development player in CA is being unrecognized in public discourses due to the sensitivity over the possible reaction of Moscow to such processes and to any developments in the region related to the engagement of other players. ${ }^{89}$

\section{CA may try to get the best deals out of Russian-Chinese competition}

The government in Moscow is eager to benefit from its eastern neighbor's economic might, while in Beijing policymakers view Russia as a critical ally on the world stage. All this suggests the two giants will aim to co-operate as much as compete, at least for the moment. As for Central Asians, Russia has accepted that "they will try to get the best deals out of this rivalry." 90

In this regards SREB laid a sound basis for cooperation between China, Russia and CA countries, and they may collaborate in creating an interconnected network of roads, transportation, pipelines, airlines, and telecommunications. ${ }^{91}$ To this

17.04.2015, p. 3. https://jamestown.org/wp-

content/uploads/2015/04/China_Brief_Vol_15_Issue_8_1.pdf

${ }^{89}$ Toktomushev K., op. cit., p. 1.

${ }^{90}$ Rising China, Sinking Russia, ..., p. 1.

${ }_{91}$ Экономический пояс Шелкового пути: новое направление дружбы и сотрудничества между Китаем и Россией, russian.china.org.cn, 24.03.2014. http://russian.china.org.cn/exclusive/txt/2014-03/24/content_31881434.htm; Экономический пояс Шелкового пути: новое направление дружбы и сотрудничества между Китаем и Россией, Центр стратегических оценок и прогнозов. 06.02.2015.

http://www.csef.ru/index.php/ru/component/content/article?id=6617:ekonomich 309 
end, in the May 2015 Putin-Xi Summit in Moscow, the two leaders signed a joint declaration "on cooperation in coordinating development of EEU (or EAEU) and SREB" reaching a new level of partnership and actually implies creation of a "common economic space" in Eurasia, ${ }^{92}$ that includes an EEU-China free trade agreement (FTA). ${ }^{93}$ In parallel, the EAEU intends to broaden the dialogue with China within the SCO and strengthen the cooperation between the two organizations. ${ }^{94}$ Actually, the EEU, SCO and OBOR projects are developing in parallel to but independently of one another, to a certain degree even creating some competition in the transport, energy, trade and economic sectors. However, scenarios are currently being considered with respect to creating a cooperation structure in which the SCO would play a central (connecting) role as the 'Eurasian bridge' between the SREB and the EEU. ${ }^{95}$

eskij-poyas-shelkovogo-puti-novoe-napravlenie-druzhby-i-sotrudnichestvamezhdu-kitaem-i-rossiej

${ }^{92}$ Eurasian Heartland: Silk Road and EEU to Solidify Sino-Russian Relations, Sputnik. 12.06.2015.

http://sputniknews.com/business/20150612/1023289572.html

${ }^{93}$ Zuenko I., Connecting the Eurasian Economic Union and the Silk Road Economic Belt: Current Problems and Challenges for Russia, China in Central Asia. 30.10.2015.

HTTP://CHINAINCENTRALASIA.COM/2015/10/30/CONNECTING-THEEURASIAN-ECONOMIC-UNION-AND-THE-SILK-ROAD-ECONOMIC-BELTCURRENT-PROBLEMS-AND-CHALLENGES-FOR-RUSSIA/

${ }^{94}$ Askar Nursha, EEU and CSTO Summits in Moscow: Another Six Months for Consideration, Institute of World Economy and Politics, Almaty, 23.12.2015. http://iwep.kz/en/kommentariy-eksperta/2015-12-25/eeu-and-csto-summits-inmoscow-another-six-months-for-consideration

${ }^{95}$ Russian-Chinese Dialogue: The 2015 Model: Report 18/2015, [Luzyanin S.G. (head) et al.; Zhao H. (head) et al.]; [I.S. Ivanov (Editor-in-Chief)], Russian 


\section{China's and Russia's competition over the guarantee of regional security}

CA has enormous security challenges, among them narcotics trafficking, religious radicalism, weak governance, and the threat of terrorism. ${ }^{96}$ Much of China's attention in CA has therefore been focused on reducing support for separatists in Xinjiang. ${ }^{97}$ Moreover, the USA withdrawal from Afghanistan could produce a vacuum in South Asia threatening stability in neighboring states. Many of the fiercest elements of the Taliban are Central Asian fighters, who gained experience and established networks in Afghanistan. Central Asian governments have already expressed concern about the return of these fighters to their home countries to continue jihad. ${ }^{98}$

Besides, China's huge investment, especially those in oil and gas in CA, is far from risk free. Rebels and extremists could damage China's economic ties and disrupt trade, and perhaps more importantly, oil and gas flows. So, Beijing has in fact found in the Central Asian states very willing partners in the struggle against religious fundamentalism. Beijing's security concerns are not confined to the integrity of the Chinese state: they also include the domestic security of neighboring states in CA and the individual governments' stability and even survival. Beijing has assisted in safeguarding these states, either indirectly through political support or directly through military co-operation. ${ }^{99}$

International Affairs Council (RIAC), Spetskniga, Moscow, 2015, p. 11.

http://russiancouncil.ru/common/upload/RIAC-Russia-China-Report-En.pdf

96 Tao Wang, Yampolsky R., op. cit., p. 1.

${ }^{97}$ Swanström N., op. cit., p. 1.

${ }^{98}$ Marantidou V., Ralph A. Cossa, op. cit., p. 2.

${ }^{99}$ Swanström N., op. cit., p. 1. 
Russia's longstanding influence in this region also offers the potential to build a mutually beneficial partnership among China, Russia, and the countries of CA. Having Russia in the partnership is especially valuable in securing existing regimes in these former Soviet Union countries and safeguarding China's long-term investment. ${ }^{100}$ Analysts expect greater competition over who will guarantee regional security, and therefore exert more influence in regional capitals. China is beginning to reassert itself as a continental power, while Russia struggles to maintain its economic and political supremacy in CA. ${ }^{101}$

However, the ruling regimes in CA tend to prioritize their own security and shape foreign policies of their countries in accordance to their perceptions and homegrown threats. As a result, whilst the Central Asian elites may demonstrate commitment to regional integration initiatives, in reality they are still unwilling to be dependent upon any new "big brother."102

\section{The USA New Silk Road Initiative for Central Asia}

In 2011, U.S. Secretary of State Hillary Clinton rolled out the plan called the New Silk Road Initiative (NSRI) as a way to build long-term stability in Afghanistan. ${ }^{103}$ The NSRI was fo-

${ }^{100}$ Tao Wang, Yampolsky R., op. cit., p. 1.

${ }^{101}$ Marantidou V., Ralph A. Cossa, op. cit., p. 2.

${ }^{102}$ Toktomushev K., The Silk Road Economic Belt's Impacts on Central Asia,

China and US Focus, China United States Exchange Foundation, 08.05.2015.

http://www.chinausfocus.com/finance-economy/the-silk-road-economic-beltsimpacts-on-central-asia/

${ }^{103}$ Joshua Kucera, Uzbekistan Starts Building Railroad to Mazar-e-Sharif, Eurasianet.org, 29.05.2010. http://www.eurasianet.org/node/61183

In the U.S. vision, Hillary Clinton said: "Turkmen gas fields could help meet both Pakistan's and India's growing energy needs and provide significant transit revenues for both Afghanistan and Pakistan. Tajik cotton could be turned into 
cused on Afghanistan as a main hub for economic integration and transportation; as well to provide the much-needed support to Afghanistan after US troops' leave the region in 2014. ${ }^{104}$ The USA and its western allies hope to bolster peace and stability in the region through supporting trade links and helping open new markets connecting Afghanistan to CA, Pakistan, and India and beyond. ${ }^{105}$ Thus an important objective of the NSRI was to provide economic boost for Afghanistan's neighbors, including Central Asian republics. The NSRI designed to promote economic growth throughout the region as well as integration into the world economy by introducing modernized infrastructure and effective cross-border trade. ${ }^{106}$ Although possessing great economic potential and vast natural resources, CA remains one of the least integrated regions in the global economy.

Indian linens. Furniture and fruit from Afghanistan could find its way to the markets of Astana or Mumbai and beyond."

${ }^{104}$ Fedorenko V., The New Silk Road Initiatives in Central Asia, Rethink Paper 10, Rethink Institute, Washington DC, August 2013, p. 4-5.

http://www.rethinkinstitute.org/wp-content/uploads/2013/11/Fedorenko-TheNew-Silk-Road.pdf

105 Zhang Hongzhou, Building the Silk Road Economic Belt: Problems and Priorities in Central Asia, Rajaratnam School of International Studies (RSIS), Nanyang Technological University, Policy Report, May 2015, p. 9.

http://www.rsis.edu.sg/wp-content/uploads/2015/05/PR150518_Building-theEconomic-Silk-Road-Belt.pdf Several projects within the U.S.-led New Silk Road (NSRI) Initiative have found monetary and strategic backing. The Central AsiaSouth Asia electricity transmission project (CASA-1000), to build transcontinental power grid lines, received US \$15 million from the U.S., a Turkmenistan-Afghanistan-Pakistan-India (TAPI) gas pipeline could receive support from both the ADB and the WB. Besides the NSRI, in February 2015, the U.S. also launched the USAID Strategy for 2015-2019 to help CA countries by significantly increasing cross-border trade and employment opportunities for the poor. ${ }^{106}$ Fedorenko V., op. cit., p. 4-5. 
However, Kazakhstan and the other CA countries did not entirely support the NSRI - the USA Republican administration's reissued concept of Greater Central Asia (GCA) - due to the fact that it was associated with the geopolitical rivalry between the USA and Russia in the region. Even back in April 2006, when Kazakh Foreign Minister supported the GCA concept, he made an important reservation arguing that GCA could be seen primarily as a civilizational and economical concept, but never in the context of military doctrine. ${ }^{107}$ Later perhaps believing that NSRI does not have obvious capacity to get implemented, the government of Kazakhstan decided to give preference to the Chinese SREB, while not denying the possible participation in NSRI. ${ }^{108}$

Some Russian experts suggest that NSRI is yielding to the Chinese SREB, because it has been engaged the highly ideological and geopolitical considerations, not the economy. The main goal of the USA and the West in general does not seem to tilt towards the economic revival of the old trade route and help the economic recovery of the CA, but rather to deter these countries away from their economic and political ties to Russia. On the contrary, China made neither ideology nor geopolitics a priority, at least when announced its OBOR initiative as China strictly speaks about and bets only on the economic benefits. ${ }^{109}$

\footnotetext{
107 Муминов А., Геополитическая «рыбалка» КНР и США в Центральной Азии... Аждар Куртов - Казахстан соблазнился блеском китайского золота, RussiansKz.Info, 18.01.2014. http://www.russianskz.info/politics/5270geopoliticheskaya-rybalka-knr-i-ssha-v-centralnoy-azii-adzhar-kurtovkazahstan-soblaznilsya-bleskom-kitayskogo-zolota.html 108 Ibid., p. 1; Астана балансирует на шелковых нитях Китая и США, Stan Radar, 17.01.2014. http://www.stanradar.com/news/full/7184-astanabalansiruet-na-shelkovyh-nitjah-kitaja-i-ssha.html 109 Астана балансирует на шелковых нитях Китая и США, .., , стр. 1.
} 
Some Chinese observers have pointed out that Washington via the NSRI was seeking to unify the CA and South Asia, the Transcaucasia and even Mongolia and Chinese Xinjiang. Moreover, the same program under the name of "Central Asian Grand Plan" has been an important part of the USA strategy of "returning" or "rebalancing" the Asia Pacific region (APR). They believe that the USA aims to control Afghanistan, but avoids investing the money, hoping that the funds will be provided by neighboring states of Afghanistan." ${ }^{110}$ India, Pakistan and other countries have already demonstrated activeness on this regard. ${ }^{11}$

Some Chinese experts assure that NSRI mainly aims to expand the USA presence in the region under the pretext of promoting security and true purpose of the White House project was and is a strategic encirclement and containment of its greatest enemy - China.

\section{The Chinese OBOR is not excluded the American initiative of NSRI}

As Forbes' contributor commented that while several USA presidential aspirants were looking inward and attacking USA participation in the North American Free Trade Agreement (NAFTA) and Transpacific Partnership (TPP) [or rolling out the plan of NSRI], China is using its economic power to build OBOR, strengthening and solidifying its links with the

\footnotetext{
110 Сергеев М. Пекин дипломатично подвинул путинский проект Евразийского союза. Независимая газета, 14.10.2013.

http://www.ng.ru/economics/2013-10-14/1_pekin.html

${ }^{111}$ Какие различия существуют в стратегиях Китая, США и России в Центральной Азии? Жэньминь Жибао, 10.10.2013.

http://russian.people.com.cn/95181/8420655.html
} 
world. ${ }^{112}$ It is no coincidence that some American experts are complaining that China, by virtue of its vibrant economy and insatiable economic demand, is stealing America's idea for the "New Silk Road" and essentially "eating their [American] lunch." "113 They are calling Washington to take the initiative in its own hands and work out long-term strategy for the CA, because if they do not, then they will either be replaced by Beijing or Moscow. ${ }^{114}$ The USA is often criticized for a distinct lack of strategy in its relations with CA. They found that unlike Beijing's economic expansion or Moscow's military ties, Washington's Central Asian policy often comes across as an afterthought. ${ }^{115}$ According to observers, a new element of Washington's approach is an explicit USA attempt to praise China's growing presence in CA, while condemning that of Russia. The presumption behind the rhetorical framing seems to be that Beijing can help check Moscow's resurging influence in the region. ${ }^{116}$

112 Harold L. (Hal) Sirkin, China Plans a New 'Silk Road' As Americans Pull Back,
Forbes, 03.152016. https://www.forbes.com/sites/haroldsirkin/2016/05/03/china-
plans-a-new-silk-road-as-americans-pull-back/\#14feead94a59
${ }^{113}$ Dena Sholk, Chinese Role in Central Asia Must not be Ignored by West,
Universal Newswires, 14.03.2013.
http://www.universalnewswires.com/centralasia/kyrgyzstan/energy/viewstory.as
px?id=13799 ${ }_{114}$ Муминов А., указ. соч., стр. 1; Астана балансирует ..., стр. 1.

${ }^{115}$ Casey M., What Is the US Policy for Central Asia? The Diplomat, 04.04.2015. http://thediplomat.com/2015/04/what-is-the-us-policy-for-centralasia/?utm_campaign=trueAnthem:+Tren

ding+Content\&utm_content=5521338404d3014998000001\&utm_medium=trueA nthem\&utm_source=facebook

${ }^{116}$ Weitz R., For U.S., Dividing China, Russia in Central Asia Easier Said Than

Done, World Politics Review, 07.04.2015.

http://www.worldpoliticsreview.com/articles/15465/for-u-s-dividing-chinarussia-in-central-asia-easier-said-than-done 
Former USA President Obama's goal of rebalancing USA foreign policy toward Asia is seen partly as an effort to contain China through USA allies such as Japan, South Korea and the Philippines - something that Beijing is quietly countering with its moves in CA. ${ }^{117}$ Facing greater competition from the USA in East Asia, Beijing is shifting attention westward to take advantage of what it perceives as a vacuum in CA. ${ }^{118}$ Nevertheless, China's Silk Road strategy is never going to replace the economic importance of its ties to the more-developed countries of the Asia-Pacific region. ${ }^{119}$ China's Pan-Asian strategic concept aims to integrate CA and western China economically with further connection of these regions into a unified communications network with inland and coastal areas of China. ${ }^{120}$ Beijing characterizes its initiatives as an effort to encourage integration and economic growth in Eurasia, rather than an attempt to expand its own political influence in the region. In this context, Chinese government officials and scholars publically contrast their plans with the post-World War II American Marshall Plan, claiming that OBOR lacks the latter's "hegemonic" characteristics. ${ }^{121}$

\footnotetext{
117 Denyer S., China bypasses American 'New Silk Road' with Two if its Own, 14.10.2013. https://www.washingtonpost.com/world/asia_pacific/chinabypasses-american-new-silk-road-with-two-if-its-own/2013/10/14/49f9f60c3284-11e3-ad00-ec4c6b31cbed_story.html?utm_term=.6138afd53337

118 Marantidou V., Ralph A. Cossa, op. cit., p. 1.

${ }^{119}$ Denyer S., op. cit., p. 1.

120 Лаумулин М. Центральная Азия в зарубежной политологии и мировой геополитике, Центральная Азия в XXI столетии, том V: КИСИ при Президенте РК, Алматы, 2009, стр. 161. http://www.kisi.kz/img/docs/4587.pdf ${ }^{121}$ Zimmerman T., The New Silk Roads: China, the U.S., and the Future of Central Asia, Center on International Cooperation, New York University, October 2015, p. 19.

http://cic.nyu.edu/sites/default/files/zimmerman_new_silk_road_final_2.pdf
} 
The Chinese OBOR, however, is not exclusive in the same manner as America's NSRI plan is, since Chinese inclusive development is designed to be formed on the basis of the differences, competition and cooperation."122 Accordingly, it is important for the USA to engage with China on OBOR, but if it is to be effective, Washington needs to be conscious that Beijing still perceives its activities in the region as intended to contain China. US initiatives in CA, which are frequently conceived with little consideration given the Sino-U.S. bilateral relationship, are often perceived in Beijing as part of a broader U.S. strategy aimed at hindering China's economic and military rise. ${ }^{123}$ However, the general harmony and occasional mutual support that China and Russia offer each other in CA will make it difficult for Washington to exploit their modest divisions. ${ }^{124}$

Yet there were limits to China's influence and control over economic and political developments in the region. China's rising influence in the region was still far from making CA its own "backyard." The influence of Moscow and, to a lesser extent, Washington on regional affairs should not be overlooked. ${ }^{125}$ If in the $19^{\text {th }}$ century, CA was the arena of the "Great Game" in which Tsarist Russia and the British Empire competed for strategic primacy, ${ }^{126}$ today, the development of the Eurasian land mass, as described by China as part of the One Belt

\footnotetext{
122 Арутюнян А., указ. соч., стр. 1.

${ }^{123}$ Zimmerman T., op. cit., p. 19.

${ }^{124}$ Weitz R., op. cit.

${ }^{125}$ Zhang Hongzhou, op. cit., p. 1.

${ }^{126}$ Ramakant Dwivedi, China's Central Asia Policy in Recent Times, China and Eurasia Forum Quarterly, Vol. 4, No. 4, Central Asia-Caucasus Institute \& Silk Road Studies Program, 2006, p. 2.

http://spol.unica.it/didattica/bonnis/Storia\%20della\%20Cina\%20Contemporanea /China\%27s\%20Central\%20Asia\%20Policy-Dwivedi.pdf
} 
initiative, could also be described as a similar venture. With the exception of a now retired Great Britain from these adventures, the major players mainly remain the same but this time led by China. ${ }^{127}$ The 21st Century version of the Great Game is on.

\section{Conclusion}

A few years ago, a trio of competing multilateral infrastructure development projects sought to advance economic interconnectedness in CA, Washington proposed a "New Silk Road Initiative" to connect Central Asian states amongst themselves and with Afghanistan. Moscow, meanwhile, launched the Eurasian Union, which was to serve, as Vladimir Putin said, as the foundation of a new "epoch" for the post-Soviet states. And China, in 2013, announced plans for its SREB, expanding railways and, most especially, energy pipeline networks in the region.

Chinese analysts pointed out that compared with the Russian EAU and American NSRI, Chinese SREB is a multi-vector project that extends to the East, West, North and South and connects the Central, East, South and West Asia in different ways of economic cooperation. SREB reflects an inclusive development of China, and China's policy of "general development of western regions" is an important step to integrate the Chinese and CA's economies. Increasing Chinese economic engagement offers CA countries an opportunity to diversify their economic relations, and stability has been a key concern for the Chinese government in its relations with CA.

\footnotetext{
127 Devonshire-Ellis C., China's Silk Road Economic Belt, China Briefing, Issue 158, Dezan Shira \& Associates, September 2015, p. 4.

http://www.leadingedgealliance.com/dev/uploads/CB\%202015\%2009\%20China's \%20Silk \%20Road\%20Economic\%20Belt.pdf
} 
Both initiatives, Russian-led EAU and USA's New Silk Road Initiative, are discussed within China's policy circles and China views the Russia-led EEU as far less of a threat. While China and Russia have clear economic incentives to cooperate in this region in the short term, they will need to overcome a number of hurdles to set their partnership on a path that can be sustained further into the future. It will be a victory for China's Good Neighbor Policy as Beijing prioritizes constructive relations with Moscow and its Eurasian neighbors.

While China has gone to great lengths to frame its initiatives in cooperative non-exclusionary terms and to emphasize its openness to a wide range of stakeholders, it also clearly intends to further establish itself as a central actor in regional affairs. China's return to CA as an economic force satisfies both premises, signaling that China has fully regained its old status as the world's premier economic power under its new leadership.

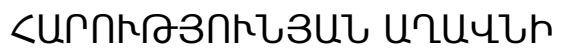 \\ 2hしuUSUนh "Ut4 9กSh, Ut4 กh2h"

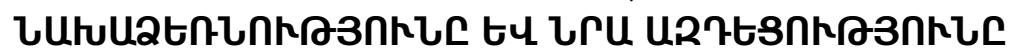 UhRhl UUhU3กhU}

furump puntip' 2prumunuiu, Tthyhu, Shptip, 4tüunnnum-

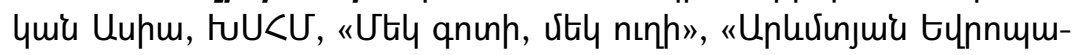

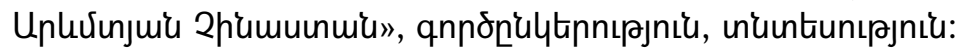

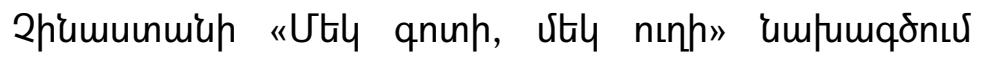

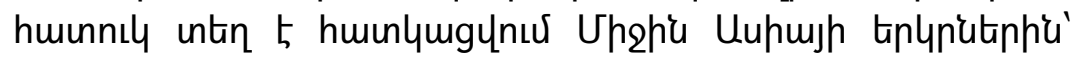

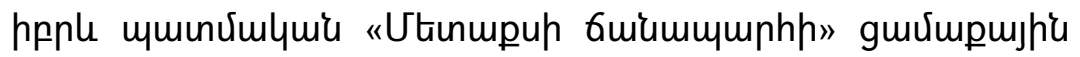

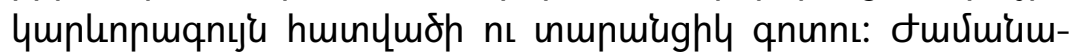

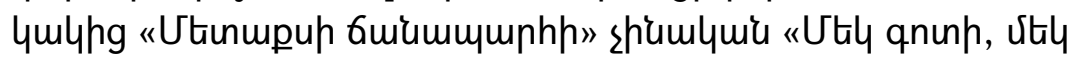




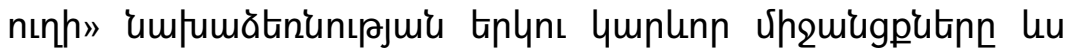

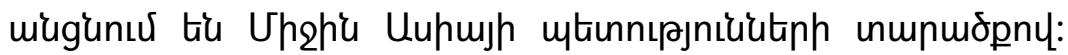

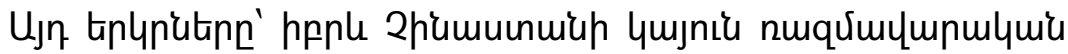

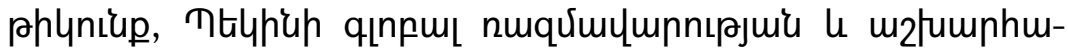

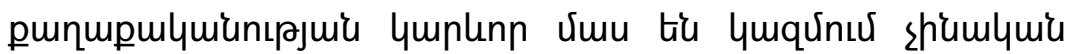

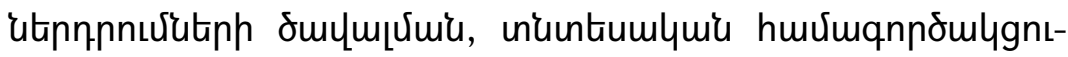

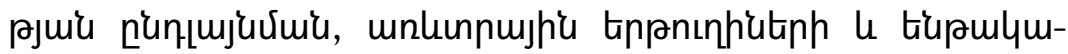

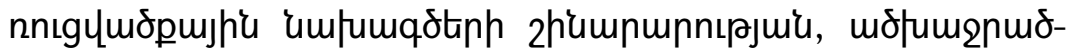

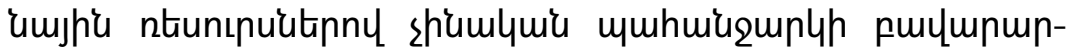

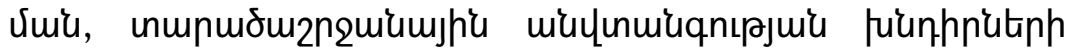

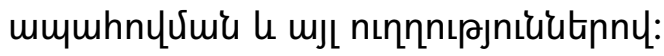

